\title{
Assessing the potential risks of industrial soil of highly industrialized and less cities on plant growth
}

\author{
Adeoti Olatunde Micheal 1, 2, ${ }^{*}$, Ige Samuel Tosin ${ }^{1}$, Abiola Adebiyi Oladepo ${ }^{1}$, Adeoye Kafilat Adenike 1, 3 and \\ Olufemi Samson Olutope ${ }^{1}$

\section{The Oke- Ogun Polytechnic, Saki Oyo State Nigeria, Department of Science Laboratory Technology, Environmental Biology Unit. \\ ${ }^{2}$ Ladoke Akintola University of Technology, Ogbomosho, P.M.B 4000, Department of Pure \& Applied Biology. ${ }^{3}$ Department of Zoology, Parasitology Unit, University of Ibadan, Nigeria.}

Publication history: Received on 28 May 2020; revised on 07 June 2020; accepted on 08 June 2020

Article DOI: https://doi.org/10.30574/gscarr.2020.3.3.0042

\begin{abstract}
Heavy metals are due to accumulate over time in the soils thereby act as a sink reservoir from which toxicants are released to the groundwater and eventually for the uptake by plants. This study was aimed at investigating the heavy metal concentrations and the consequent effects on two common food crops (maize and cowpea). Three sites of ten soil samples at two points ( 0 and 50 meters apart) were collected with two samples from various manufacturing area of: Sango-Otta (highly industrialized), Oluyole industrial estate (less industrialized) and Saki with no industrial activities. Suitable spot nearest to the production area on the site were located and fifty meters away from the first site. The top soil layer was scrapped off using a shovel, and a portion of soil was scooped inclining the shovel beneath the earth. Soil samples were collected from depths of one feet and four feet respectively. The sample were put in a clean plastic container weighing about $200 \mathrm{~g}$ and was subsequently air dried and transported to the laboratory for test. Concentrations of heavy metals were found to be very high in the highly industrialized than in the less industrialized cities. Conversely, the F-calculated value was $2.906>0.096^{\mathrm{b}}$ which was significant in soil samples of post-planting in cowpea, and the F-calculated value was $1.021>0.319^{\mathrm{b}} \mathrm{F}$-Sig for the soil samples post planting in Zea mays. As reported in this study, the concentration of heavy metals impacted on the field performance of the selected crops. The concentration of heavy metals in the soil should be continuously monitored by farmers before planting especially those in the highly industrialized cities.
\end{abstract}

Keywords: Groundwater; Industrialized; Spectrophotometer; Toxicants; Post-planting.

\section{Introduction}

Contamination of the environment by heavy metals due to certain industrial activities has been on the rise in recent times. Toxicity of these compounds has been reported extensively [1, 2, 3]. They accumulate over time in soils which act as a sink from which these toxicants are released to the groundwater and plants, and end up through the food chain in man thereby causing various toxicological manifestations. Occupationally exposed individuals to Lead poisoning tend to have high blood pressure [4], and are at an increased risk for cardio-vascular diseases, myocardial infarction and stroke [2]. The effect can be acute or chronic nephropathy and others are gastrointestinal disturbances-abdominal pain, cramps, constipation, anorexia and weight loss, immune suppression, and slight liver impairment [5].

Toxicity of Chromium is associated with allergic condition in humans; arsenic is associated with skin damage, increased risk of cancer and problems with circulatory system while mercury is associated with kidney damage [6]. Aluminum toxicity has been shown to produce excessive headaches, abnormal heart rhythm, and depression, numbness of the

\footnotetext{
${ }^{*}$ Corresponding author: Adeoti Olatunde Micheal
} 
hands and feet and blurred vision [7]. Other effects of aluminum include: impairment in choice reaction time, long-term memory, psychomotor speed [8]. Heavy metals occur in the environment naturally and are released during anthropogenic activities. Soil contamination with heavy metals results from human-related activities such as mining [9], smelting procedures [10] and agriculture [11] as well as earth-related activities. Chemical and metallurgical industries are the most important sources of heavy metals in the environment, sewage-treated sludge, known as biosolids and used as fertilizers on the soil can contribute to heavy metal levels in the soil [12]. [13] and [14] opined that major sources of contamination are by the accumulation of heavy metals and metalloids through emissions from the rapidly expanding industrial areas, mine tailings, disposal of high metal wastes, leaded-gasoline and paints, land application of fertilizers, animal manures, sewage sludge, pesticides, wastewater irrigation, coal combustion residues, spillage of petrochemicals and atmospheric deposition. Particularly, zinc and cadmium may also be added to soils adjacent to roads, the sources being car tyres and lubricant oils [15].

Each contamination source has peculiar damaging effects on plants and animals and consequently on human health, but sources that add heavy metals to soils and waters are of serious concern due to their persistence in the environment and carcinogenic tendencies to humans. They cannot be destroyed biologically but are only transformed from one oxidation state or organic complex to another $[16,17]$. Therefore, heavy metal pollution poses a great potential threat to the environment and human health. In most countries (developed and developing alike), despite overwhelming literature on the toxicity of these metals, avoidable contaminations are on the rise. Recent studies on some New Zealand soils treated with bio-solids have shown increased concentrations of cadmium, nickel and zinc in drainage leachates $[18,19]$. In the United States, an estimated $70 \%$ of heavy metals in landfills come from discarded electronics, further buttressing the potential toxicity tendencies on the residents. Soil pollution is also a serious challenge in China, where one-sixth of total arable land has been polluted by heavy metals, and more than $40 \%$ has been degraded to varying degree due to erosion and desertification. In Western Europe, over a million sites were affected by heavy metals [20], of which, over 300000 were contaminated, and the estimated total number in Europe could be much larger, as a result of the contribution from the Central and Eastern European countries [21].

In Nigeria in 2010, there was a report of over 300 deaths in Zamfara state due to Lead contamination [22]. On the whole, all countries have been affected with soil heavy metals contamination through one source or the other, though at varying rates and intensities. Monitoring the endangerment of soil with heavy metals is of interest due to their influence on groundwater and surface water [23,24], on plants [25,26] on animals and humans [27, 28,29] and on any entity that has life. The aim of this study was to determine to what extent, human and industrial activities have affected the quality of soil due to contamination of soil with heavy metals and the consequent effects on the health status of the inhabitants. Soils play a critical role in delivering ecosystem services. Management to change an ecosystem process in support of one regulating ecosystem service can either provide co-benefits to other services or require trade-offs [30,31]. Recent reviews have provided examples of some of these synergies and trade-offs and illustrated the role of soils in supporting ecosystem services and underpinning natural capital [30,31,32].

\section{Material and methods}

\subsection{Materials}

Materials used for the study were cowpea, Zea mays, soil samples, plastic container, digger, shovel, masking tape, nose cover, hand gloves, goggle, meter rule, measuring tape, watering can, and soil test kits (Luster leaf rapidest soil test kit No. 1601).

\subsubsection{Source of soil sample}

The soil samples for this study were collected from three different locations classified according to the concentration of industries into: highly industrialized (Sango-otta) area, less industrialized area (Oluyole), and non-industrialized (Saki). The first category included was Sango-otta Lagos - Abeokuta express way which was located at 6043'18”N, $3^{0} 13^{\prime} 09^{\prime \prime} \mathrm{E}$, with an estimated 526,565 (2006 population census) residents living in or around it. Oluyole industrial estate, Oluyole Ibadan in Oyo State $7^{0} 21^{\prime} 26^{\prime \prime} \mathrm{N}, 3^{0} 50^{\prime} 58^{\prime \prime}$, with an approximately 204,000 (2006 population census). And lastly an area with no industrial activities: Saki, 8038'12"N, 3024'16"E, total population of 388,225 (2006 population census).

\subsection{Sampling Technique}

For collection of the soil samples a suitable spot nearest to the production area on the site were located at fifty meters away from the first site. The top soil layer was scrapped off using a shovel, and a portion of soil was scooped inclining the shovel beneath the earth. A hole one to four feet was dug. Soil samples were collected from depths of one feet and 
four feet. The samples were put in a clean plastic container, of about $200 \mathrm{~g}$ was air dried and transported to the laboratory for macronutrient test, $\mathrm{pH}$ test, and heavy metal analysis.

\subsubsection{Procedure for $\mathrm{pH}$ test}

The green comparator was removed and take out the package of capsules, fill test chamber to soil fill line with soil sample. Holding the capsule horizontally over the test chamber, carefully separate the two halves of the green capsule and pour powder into the test chamber. Using the dropper provided, add distilled water to fill line. Fit the cap onto comparator, making sure it is seated properly and caps tightly. Shake thoroughly. Allow soil to settle and colour to develop for about a minute. Compare colour of solution against $\mathrm{pH}$ chart.

\subsubsection{Procedure for macronutrients test}

A clean container was filled with 1 cup of soil and 5 cups of water after it was thoroughly shaken; the soil and water together for at least one minute; then the mixture was allowed to stand undisturbed until it settled to have a clear solution for about 24 hours. The mixture was selected with the appropriate comparator for the test by removing the cap and taken out; the capsules were the same colour as the cap. By using the dropper provided with the kit, the test chambers was filled up to mark on the chart with solution from the soil sample. The test chamber were held horizontally over the test chamber, by carefully separated the two halves of the green capsule and the powder was poured into the test chamber. The cap on the comparator was made to be seated properly and the caps were tightly capped. This was shaken thoroughly in order to allow the colour to develop for 10 minutes. This was compared with the colour of the solution in the test chamber to the colour chart.

\subsubsection{Procedure for heavy metals analysis}

The soil sample was sieve-dried soil with 0.5 mesh sieve and weight of 0.5 grams of the $0.5 \mathrm{~mm}$ sieved soil into a $75 \mathrm{ml}$ beaker. About $5 \mathrm{mls}$ of acid was diluted in (3:1 Nitric acid and Perchloric acid) to the soil in the beaker and placed the beaker on a laboratory hotplate at $80^{\circ} \mathrm{C}$ and heat for $25-30$ mins for digestion to occur. This was heated until a light yellowish fluid/creamy substance was obtained". After digestion, the beaker was allowed to cool and then make up the digest to $25 \mathrm{~mL}$ in a standard volumetric flask with distilled water. This was diluted (if necessary), and then read the digest for the presence and concentration of Heavy metals using the AAS (atomic absorption spectrophotometer) machine. The soil samples were replicated in a perforated container. Four healthy seeds of Zea mays and cowpea were planted on each replicate. The seeds were periodically wet with water every day for twenty-eight consecutive days. About $200 \mathrm{~g}$ of the soil sample was air dried and transported to the laboratory for post-planting analysis.

\section{Results}

Table $1 \mathrm{pH}$ and micronutrients analysis result pre planting.

\begin{tabular}{|c|c|c|c|c|}
\hline & pH & Nitrogen & Phosphorus & Potash \\
\hline \multirow[t]{2}{*}{$S_{1} 1 \mathrm{ft}$} & 6.0 & $\mathrm{~N}_{1}$ & $\mathrm{P}_{3}$ & Ko \\
\hline & Acid & Deficient & Sufficient & Depleted \\
\hline \multirow[t]{2}{*}{$\mathrm{S}_{1} 4 \mathrm{ft}$} & 7.0 & $\mathrm{~N}_{1}$ & $\mathrm{P}_{2}$ & $\mathrm{~K}_{2}$ \\
\hline & Neutral & Deficient & Adequate & Adequate \\
\hline \multirow[t]{2}{*}{$\mathrm{S}_{2} 1 \mathrm{ft}$} & 7.5 & $\mathrm{~N}_{1}$ & $\mathrm{P}_{1}$ & Ko \\
\hline & Alkaline & Deficient & Deficient & Depleted \\
\hline \multirow[t]{2}{*}{$\mathrm{S}_{2} 4 \mathrm{ft}$} & 7.0 & $\mathrm{~N}_{2}$ & $\mathrm{P}_{1}$ & Ko \\
\hline & Neutral & Adequate & Deficient & Depleted \\
\hline \multirow[t]{2}{*}{$\mathrm{I}_{1} 1 \mathrm{ft}$} & 7.5 & $\mathrm{~N}_{2}$ & $\mathrm{P}_{2}$ & $\mathrm{~K}_{1}$ \\
\hline & Alkaline & Adequate & Adequate & Deficient \\
\hline \multirow[t]{2}{*}{$\mathrm{I}_{1} 4 \mathrm{ft}$} & 7.0 & $\mathrm{~N}_{1}$ & $\mathrm{P}_{1}$ & Ko \\
\hline & Neutral & Deficient & Deficient & Depleted \\
\hline \multirow[t]{2}{*}{$\mathrm{I}_{2} 1 \mathrm{ft}$} & 7.0 & $\mathrm{~N}_{\mathrm{o}}$ & Po & Ko \\
\hline & Neutral & Depleted & Depleted & Depleted \\
\hline \multirow[t]{2}{*}{$\mathrm{I}_{2} 4 \mathrm{ft}$} & 6.5 & $\mathrm{~N}_{1}$ & $\mathrm{P}_{1}$ & Ko \\
\hline & Slight acid & Deficient & Deficient & Depleted \\
\hline \multirow[t]{2}{*}{$\mathrm{SC}_{1} 1 \mathrm{ft}$} & 6.5 & $\mathrm{~N}_{\mathrm{o}}$ & Po & $\mathrm{K}_{1}$ \\
\hline & Slight Acid & Depleted & Depleted & Deficient \\
\hline \multirow[t]{2}{*}{$\mathrm{SC}_{1} 4 \mathrm{ft}$} & 6.5 & $\mathrm{~N}_{3}$ & $\mathrm{P}_{3}$ & $\mathrm{~K}_{1}$ \\
\hline & Slight acid & Sufficient & Sufficient & Deficient \\
\hline
\end{tabular}


Table $2 \mathrm{pH}$ and micronutrients analysis post planting Cowpea

\begin{tabular}{lllll}
\hline & pH & Nitrogen & Phosphorus & Potash \\
\hline $\mathrm{S}_{1} 1 \mathrm{ft}$ & 7.0 & $\mathrm{~N}_{1}$ & $\mathrm{P}_{1}$ & Ko \\
& Neutral & Deficient & Deficient & Depleted \\
$\mathrm{S}_{1} 4 \mathrm{ft}$ & 7.0 & No & Po & $\mathrm{K}_{1}$ \\
& Neutral & Depleted & Depleted & Deficient \\
$\mathrm{S}_{2} 1 \mathrm{ft}$ & 7.5 & $\mathrm{~N}_{2}$ & $\mathrm{P}_{1}$ & Ko \\
& Alkaline & Adequate & Deficient & Depleted \\
$\mathrm{S}_{2} 4 \mathrm{ft}$ & 7.5 & $\mathrm{~N}_{1}$ & $\mathrm{P}_{2}$ & K0 \\
& Alkaline & Deficient & Adequate & Depleted \\
$\mathrm{I}_{1} 1 \mathrm{ft}$ & 6.5 & $\mathrm{~N}_{2}$ & $\mathrm{P}_{2}$ & $\mathrm{~K}_{2}$ \\
& Slight acid & Adequate & Adequate & Adequate \\
$\mathrm{I}_{1} 4 \mathrm{ft}$ & 7.5 & $\mathrm{~N}_{1}$ & $\mathrm{P}_{1}$ & Ko \\
& Alkaline & Deficient & Deficient & Depleted \\
$\mathrm{I}_{2} 1 \mathrm{ft}$ & 7.5 & $\mathrm{No}$ & $\mathrm{P}_{1}$ & Ko \\
& Alkaline & Depleted & Deficient & Depleted \\
$\mathrm{I}_{2} 4 \mathrm{ft}$ & 7.5 & $\mathrm{~N}_{2}$ & $\mathrm{P}_{2}$ & $\mathrm{~K}_{2}$ \\
& Alkaline & Adequate & Adequate & Adequate \\
$\mathrm{SC}_{1} 1 \mathrm{ft}$ & 7.0 & $\mathrm{~N}_{2}$ & $\mathrm{P}_{1}$ & Ko \\
& Neutral & Adequate & Deficient & Adequate \\
$\mathrm{SC}_{1} 4 \mathrm{ft}$ & 7.0 & $\mathrm{~N}_{1}$ & $\mathrm{P}_{1}$ & K2 \\
& Neutral & Adequate & Deficient & Adequate \\
$\mathrm{SC}_{1} 4 \mathrm{ft}$ & 7.0 & $\mathrm{~N}_{1}$ & P & Ko \\
& Neutral & Deficient & Deficient & Depleted \\
\hline
\end{tabular}

Table $3 \mathrm{pH}$ and micro nutrients analysis post planting Zea mays

\begin{tabular}{lllll}
\hline & pH & Nitrogen & Phosphorus & Potash \\
\hline $\mathrm{S}_{1} 1 \mathrm{ft}$ & 7.0 & $\mathrm{~N}_{1}$ & P1 & Ko \\
& Neutral & Deficient & Deficient & Depleted \\
$\mathrm{S}_{1} 4 \mathrm{ft}$ & 7.0 & $\mathrm{~N}_{1}$ & $\mathrm{P}_{3}$ & $\mathrm{~K}_{3}$ \\
& Neutral & Deficient & Sufficient & Sufficient \\
$\mathrm{S}_{2} 1 \mathrm{ft}$ & 7.5 & $\mathrm{~N}_{2}$ & Po & Ko \\
& Alkaline & Adequate & Depleted & Depleted \\
$\mathrm{S}_{2} 4 \mathrm{ft}$ & 7.5 & $\mathrm{~N}_{1}$ & $\mathrm{P}_{1}$ & Ko \\
& Alkaline & Deficient & Deficient & Depleted \\
$\mathrm{I}_{1} 1 \mathrm{ft}$ & 7.0 & $\mathrm{~N} 1$ & Po & Ko \\
& Neutral & Deficient & Deficient & Depleted \\
$\mathrm{I}_{1} 4 \mathrm{ft}$ & 7.5 & $\mathrm{~N}_{1}$ & Po & Ko \\
& Alkaline & Deficient & Depleted & Depleted \\
$\mathrm{I}_{2} 1 \mathrm{ft}$ & 7.0 & $\mathrm{~N}_{1}$ & $\mathrm{P}_{1}$ & Ko \\
& Neutral & Deficient & Deficient & Depeleted \\
$\mathrm{I}_{2} 4 \mathrm{ft}$ & 7.5 & $\mathrm{~N}_{\mathrm{i}}$ & $\mathrm{P}_{3}$ & K2 \\
& Alkaline & Deficient & Sufficient & Adequate \\
$\mathrm{SC}_{1} \mathrm{Ift}$ & 6.5 & $\mathrm{Ni}$ & $\mathrm{P}_{2}$ & K \\
& Slight acid & Depleted & Adequate & Adequate \\
$\mathrm{SC}_{1} 4 \mathrm{ft}$ & 7.0 & $\mathrm{~N}_{1}$ & $\mathrm{P}_{2}$ & Ko \\
\hline
\end{tabular}


Table 4 Soil Sample Results (Pre-planting)

\begin{tabular}{lllllll}
\hline No & Site-code & Feet & $\mathbf{C o} \mathbf{M g} / \mathbf{K g}$ & $\mathbf{C d ~} \mathbf{M g} / \mathbf{K g}$ & $\mathbf{P b ~ M g} / \mathbf{K g}$ & $\mathbf{N i ~ M g} / \mathbf{K g}$ \\
\hline 1 & SC1 & 1 & 2.65 & 49.35 & 22.25 & 16.70 \\
2 & SC1 & 4 & 2.10 & 59.65 & 28.75 & 32.85 \\
3 & S1 & 1 & 1.75 & 44.90 & 23.45 & 15.80 \\
4 & S1 & 4 & 1.90 & 47.60 & 29.15 & 21.50 \\
5 & S2 & 1 & 3.25 & 64.20 & 34.4 & 20.60 \\
6 & S2 & 4 & 8.95 & 58.35 & 34.85 & 38.40 \\
7 & I1 & 1 & 8.50 & 54.15 & 20.30 & 20.95 \\
8 & I1 & 4 & 8.95 & 61.95 & 32.80 & 27.20 \\
9 & I2 & 1 & 9.70 & 59.90 & 19.45 & 27.10 \\
10 & I2 & 4 & 10.75 & 54.05 & 37.70 & 29.85 \\
\hline
\end{tabular}

Table 5 Post planting cowpea heavy metals results

\begin{tabular}{llllllll}
\hline No & Sample code & Site-code & Feet & Co $\mathbf{~ M g} / \mathbf{K g}$ & $\mathbf{C d ~ M g} / \mathbf{K g}$ & $\mathbf{P b ~ M g} / \mathbf{K g}$ & $\mathbf{N i ~ M g} / \mathbf{K g}$ \\
\hline 1 & A Cowpea & SC1 & 1 & 6.85 & 47.1 & 43.65 & 20.70 \\
2 & B Cowpea & SC1 & 4 & 6.50 & 50.50 & 36.30 & 26.20 \\
3 & C Cowpea & S1 & 1 & 5.80 & 50.00 & 33.05 & 21.50 \\
4 & D Cowpea & S1 & 4 & 6.05 & 60.00 & 27.10 & 27.25 \\
5 & E Cowpea & S2 & 1 & 7.20 & 56.00 & 36.35 & 18.75 \\
6 & F Cowpea & S2 & 4 & 5.65 & 52.10 & 46.95 & 15.95 \\
7 & G Cowpea & I1 & 1 & 8.90 & 60.90 & 44.85 & 17.35 \\
8 & H Cowpea & I1 & 4 & 7.90 & 62.80 & 44.80 & 46.55 \\
9 & I Cowpea & I2 & 1 & 6.85 & 62.75 & 39.35 & 22.15 \\
10 & J Cowpea & I2 & 4 & 9.80 & 74.85 & 49.75 & 83.35 \\
\hline
\end{tabular}

Table 6 Soil Sample Results Post Planting Zea mays

\begin{tabular}{llllllll}
\hline No & Sample code & Site-code & Feet & Co $\mathbf{~ M g} / \mathbf{K g}$ & $\mathbf{C d ~ M g} / \mathbf{K g}$ & $\mathbf{P b ~ M g} / \mathbf{K g}$ & $\mathbf{~ N i ~ M g / K g}$ \\
\hline 1 & A Maize & SC1 & 1 & 9.25 & 73.80 & 45.70 & 52.60 \\
2 & B Maize & SC1 & 4 & 8.75 & 61.95 & 44.70 & 23.05 \\
3 & C Maize & S1 & 1 & 9.65 & 56.05 & 52.10 & 13.05 \\
4 & D Maize & S1 & 4 & 11.30 & 48.45 & 48.40 & 7.95 \\
5 & E Maize & S2 & 1 & 10.85 & 64.00 & 62.50 & 24.80 \\
6 & F Maize & S2 & 4 & 11.35 & 72.65 & 49.00 & 28.20 \\
\hline
\end{tabular}




\begin{tabular}{llllllll}
\hline 7 & G Maize & I1 & 1 & 12.05 & 65.45 & 73.30 & 25.65 \\
8 & H Maize & I1 & 4 & 11.60 & 63.10 & 55.95 & 24.20 \\
9 & I Maize & I2 & 1 & 11.40 & 71.65 & 63.65 & 28.45 \\
10 & J Maize & I2 & 4 & 10.75 & 70.75 & 64.55 & 21.85 \\
\hline
\end{tabular}

Table 7 Showing the soil sample result analysis

\begin{tabular}{|c|c|c|c|c|c|c|}
\hline \multicolumn{2}{|c|}{ Model } & \multirow{2}{*}{$\begin{array}{l}\text { Sum of Squares } \\
1.693\end{array}$} & \multirow{2}{*}{$\frac{\text { Df }}{1}$} & \multirow{2}{*}{$\frac{\text { Mean Square }}{1.693}$} & \multirow{2}{*}{$\frac{\mathbf{F}}{1.331}$} & \multirow{2}{*}{$\begin{array}{l}\text { Sig. } \\
.256 b\end{array}$} \\
\hline 1 & Regression & & & & & \\
\hline & Residual & 48.307 & 38 & 1.271 & & \\
\hline & Total & 50.000 & 39 & & & \\
\hline
\end{tabular}

Table 8 Post planting effect on Cowpea

\begin{tabular}{|c|c|c|c|c|c|c|}
\hline \multicolumn{2}{|c|}{ Model } & \multirow{2}{*}{$\begin{array}{l}\text { Sum of Squares } \\
3.552\end{array}$} & \multirow{2}{*}{$\frac{\text { Df }}{1}$} & \multirow{2}{*}{$\frac{\text { Mean Square }}{3.552}$} & \multirow{2}{*}{$\begin{array}{l}\mathbf{F} \\
2.906\end{array}$} & \multirow{2}{*}{$\begin{array}{l}\text { Sig. } \\
.096 \mathrm{~b}\end{array}$} \\
\hline 1 & Regression & & & & & \\
\hline & Residual & 46.448 & 38 & 1.222 & & \\
\hline & Total & 50.000 & 39 & & & \\
\hline
\end{tabular}

Table 9 Post planting effect on Zea mays

\begin{tabular}{lllllll}
\hline Model & & Sum of Squares & Df & Mean Square & F & Sig. \\
\hline 1 & Regression & 1.308 & 1 & 1.308 & 1.021 & $.319 \mathrm{~b}$ \\
& Residual & 48.692 & 38 & 1.281 & & \\
Total & 50.000 & 39 & & & \\
\hline
\end{tabular}

\section{Discussion}

A comprehensive analysis of published data indicates that heavy metals such as arsenic cadmium, chromium, lead, and mercury, occur naturally. However, anthropogenic activities contribute significantly to environmental contamination. These metals are systemic toxicants known to induce adverse health effects in humans, including cardiovascular diseases, developmental abnormalities, neurologic and neurobehavioral disorders, diabetes, hearing loss, hematologic and immunologic disorders, and various types of cancer. The main pathways of exposure include ingestion, inhalation, and dermal contact. Recent reports have pointed out that these toxic elements may interfere metabolically with nutritionally essential metals such as iron, calcium, copper, and zinc [33,34]. In table 7, 8, and 9 above, there was significant effect of heavy metals on pre planting and post planting of cowpea planted as well as in the soil where maize was grown. These results were all expected because of the concentration of industries in these areas. Also, Nitrogen, Phosphorus and Potash were found to be deficient in the highly industrialized and the less industrialized which indicated that the soil should not be used for agricultural purpose even though the $\mathrm{pH}$ was and Neutral. In the same vein concentrations in (mg/kg) of Cobalt (Co), Cadmium (Cd), Lead (Pb), Nickel (Ni) of soil samples were depicted in Table 4-6. The result of data used to test the first null hypothesis revealed that the sum of squares between regressions was 1.693 with a mean square of 1.693. Similarly, the sum of squares within residual is 48.307 with a mean square of 1.271 . The degrees of freedom were 1 and 39 respectively. The F-calculated was 1.331 greater than $0.256^{\mathrm{b}}$ F-Sig. The null hypothesis $\left(\mathrm{H}_{0}\right)$ was Rejected since F-calculated was greater than F-obtained. The result of data used to test the first null hypothesis revealed that the sum of squares between regressions was 3.552 with a mean square of 3.552. Similarly, the sum of squares within residual was 46.448 with a mean square of 1.222 . The degrees of freedom are 1 and 39 respectively. The F-calculated value was 2.906 $>0.096^{\mathrm{b}} \mathrm{F}$-Sig. The $\mathrm{H}_{0}$ was Rejected since F-calculated was greater than 
F-sig. The result corroborated earlier studies of $[23,26]$ which invariably showed that there is effect of heavy metals in the post planting cowpea soil sample.

Furthermore, the result of data used to test the first null hypothesis reveals that the sum of squares between regressions is 1.308 with a mean square of 1.308 . Similarly, the sum of squares within residual is 48.692 with a mean square of 1.281. The degrees of freedom are 1 and 39 respectively. The F-calculated value was $1.021>0.319^{b} \mathrm{~F}-\mathrm{Sig}$. $\mathrm{H}_{0}$ was Rejected too since F-calculated was greater than F-sig. The result indicated that there was an effect of heavy metals on post planting maize soil sample.

The progression of metal accumulation in soil samples did not only indicated the level of current contamination but could also portray an history of activities over a long period of time since soil serves as a sink for these contaminants $[35,36]$. All the metal ions analyzed were present in varying concentrations. Various agencies including World Health Organization (WHO), United States Environmental Protection Agency (US-EPA) and European Regulatory Standards (EURS) have set different maximum contaminant limits for heavy metals. The maximum recommended by EURS for soil samples are: cadmium $3 \mathrm{mg} / \mathrm{kg}$; lead $150 \mathrm{mg} / \mathrm{kg}$. Heavy metals were the most dangerous because they tend to bio accumulate over time [3].

\section{Recommendations}

The following could be recommended from this study:

- The levels of heavy metals in the soil should be continuously monitored to check on their levels. Heavy metals levels in the soil. The heavy metals are very poisonous even in their smallest quantities.

- Sources of heavy metals in soils like inorganic fertilizers, pesticides and acaricides need to be controlled. Fertilizers, pesticides and acaricides are known to be the sources of some of the heavy metals like lead, zinc and $\mathrm{Cd}$ which have been detected in the soil samples.

- Governments should promote harmonized data collection, research, legislation and regulations, and consider the use of indicators

- Precautionary measures should thus be taken to avoid chronic toxicity in humans resulting from planting food crops on soils in high-exposure areas and other human activities which can cause ingestion of edibles contaminated with these metals.

\section{Conclusion}

This study obtained these heavy metals: Cobalt (Co), Cadmium (Cd), Lead (Pb), and Nickel (Ni) in higher concentration in the study areas. Heavy metals have been proven to be toxic to both human and environmental health. Owing to their toxicity and their possible bioaccumulation, these compounds should be subjected to mandatory monitoring. Several suitable separation and detection methods are available for laboratories engaged in daily routine analysis of a large number of biological or environmental samples.

\section{Compliance with ethical standards}

\section{Acknowledgments}

The authors appreciate all the management staff of the selected companies for granting approval to undertake this study un-hindered.

\section{Disclosure of conflict of interest}

The authors hereby declare a no-conflict of interest submission during and none shall arise even thereafter.

\section{References}

[1] Dupler D. (2001). Heavy metal poisoning. Gale Encyclopedia of Alternative Medicine. Farmington Hills, MI: Gale Group. 
[2] Momodu M and Anyakora C. (2010). Heavy metal contamination of groundwater: the Surulere case study. Res. J. Environ. Earth Sci, 2(1), 29-43.

[3] Anyakora C, Nwaeze K, Awodele O, Nwadike C, Arbabi M and Coker H. (2011). Concentrations of Heavy Metals in some Pharmaceutical Effluents in Lagos, Nigeria. Journnal of Environtal Chemistry and Ecotoxicology, 3(2), 2531.

[4] Pocock SJ, Shaper AG, Ashby D, Delves T and Whitehead TP. (1984). Blood lead concentration, blood pressure, and renal function. Br. Med. J, 289, 872-874.

[5] Goyer RA. (1988). Lead. In: Handbook on Toxicity of Inorganic Compounds. H.G. Seiler and H. Sigel, eds. Marcel Dekker, Inc.: New York, 359-382.

[6] Scragg, A. (2006). Environmental Biotechnology. Oxford University Press, Oxford, UK, 2nd edition.

[7] Kilburn KH and Warshaw RH. (1993). Neurobehavioral testing of subjects exposed residually to groundwater contaminated from an aluminum die-casting plant and local referents. Journal of Toxicology and Environ. Health, 39, 483-496.

[8] Willis MR and Savory J. (1985). Water content of aluminum, dialysis dementia, and osteomalacia. Environmental Health Perspectives, 63, 141-147.

[9] Navarro MC, Pérez-Sirvent C, Martínez-Sánchez MJ, Vidal J, Tovar PJ and Bech J. (2008). Abandoned mine sites as a source of contamination by heavy metals: A case study in a semi-arid zone. J. Geo. Expl, 96(2-3), 183-193.

[10] Brumelis G, Brown DH, Nikodemus $O$ and Tjarve D. (1999). The monitoring and risk assessment of Zn deposition around a metal smelter in Latvia. Environmental Monitoring and Assessment, 58(2), 201-212.

[11] Vaalgamaa S and Conley DJ. (2008). Detecting environmental change in estuaries: Nutrient and heavy metal distributions in sediment cores in estuaries from the Gulf of Finland, Baltic Sea. Estuarine Coast Shelf Sci, 76(1), 45-56.

[12] Snyder C. (2005). The dirty work of promoting "recycling" of America's sewage sludge. International Journal Occupation Environmental Health, 11(4), 415-27.

[13] Khan S, Cao Q, Zheng YM, Huang YZ and Zhu YG. (2008). Health risks of heavy metals in contaminated soils and food crops irrigated with wastewater in Beijing, China. Environmental Pollution, 152(3), 686-692.

[14] Zhang Q, Zhang L, Xiao X, Su Z, Zou P, Hu H, Yadong Huang Y and Qing-Yu H. (2010). Heavy metals chromium and neodymium reduced phosphorylation level of heat shock protein 27 in human keratinocytes. Toxicology In Vitro, $24,1098-1104$.

[15] United States Environmental Protection Agency USEPA. (1996). Report: recent Developments for In Situ Treatment of Metals contaminated Soils. U.S. Environmental Protection Agency, Office of Solid Waste and Emergency Response.

[16] Garbisu C and Alkorta I. (2001). Phytoextraction: A cost effective plant-based technology for the removal of metals from the environment. Bio-resources Technol, 77(3), 229-236.

[17] Gisbert C, Ros R, de Haro A, Walker DJ, Pilar Bernal M, Serrano R and Avino JN. (2003). A plant genetically modified that accumulates $\mathrm{Pb}$ is especially promising for phytoremediation. Biochemical Biophysical. Research Community, 303(2), 440-445.

[18] Keller C, McGrath SP and Dunham SJ. (2002). Trace metal leaching through a soil-grassland system after sewage sludge application. Journal Environ Quality, 31(5), 1550-1560.

[19] McLaren RG, Clucas LM and Taylor MD. (2004). Leaching of macronutrients and metals from undisturbed soils treated with metal-spiked sewage sludge. Australian Journal of Soil Research, 43(2), 159-170.

[20] McGrath SP, Zhao FJ and Lombi E. (2001). Plant and rhizosphere process involved in phytoremediation of metalcontaminated soils. Plant Soil, 232(1/2), 207-214.

[21] Gade LH. (2000).Highly polar metal - Metal bonds in "early-late" heterodimetallic complexes. Angewandte Chemie-International Edition, 39(15), 2658-2678.

[22] Chimezie Anyakora, Teddy Ehianeta and Oghenetega Umukoro. (2013). Heavy metal levels in soil samples from highly industrialized lagos environment. Department of pharmaceutical chemistry university of Lagos, 7(9), 917924. 
[23] Wieting J. (1988). Effects of air-pollutants on groundwater quality in the Federal Republic of Germany. Wasser Boden, 40(4), 183-186.

[24] Stimpfl E, Aichner M, Cassar A, Thaler C, Andreaus O and Matteazzi A. (2006). The state of fruit orchard soils in South Tyrol (Italy). Laimburg J, 3(1), 74-134.

[25] Stobrawa K and Lorenc-Plucińska G. (2008). Thresholds of heavy-metal toxicity in cuttings of European black poplar (Populus nigra L.) determined according to antioxidant status of fine roots and morphometrical disorders. Sci. Total Environ, 390(1), 86-96.

[26] Lagisz M and Laskowski R. (2008). Evidence for between-generation effects in carabids exposed to heavy metals pollution. Ecotoxicology, 17(1), 59-66.

[27] De Vries W, Romkens PF and Schutze G. (2007). Critical soil concentrations of cadmium, lead, and mercury in view of health effects on humans and animals. Rev. Environ. Contam. Toxicol, 191, 91-130.

[28] Korashy HM and El-Kadi AOS. (2008). Modulation of TCDD-mediated induction of cytochrome P450 1A1 by mercury, lead, and copper in human HepG2 cell line. Toxicology in vitro, 22(1), 154-158.

[29] Robinson DA, Hockley N, Cooper DM, Emmett BA, Keith AM, Lebron I, Reynolds B, Tipping E, Tye AM, Watts CW, Whalley WR, Black HIJ, Warren GP and Robinson JS. (2013). Natural capital and ecosystem services, developing an appropriate soils framework as a basis for valuation. Soil Biology and Biochemistry, 57, 1023-1033.

[30] Smith P, Ashmore M, Black H, Burgess PJ, Evans C, Quine T, Thomson AM, Hicks K and Orr H. (2013). The role of ecosystems and their management in regulating climate, and soil, water and air quality. Journal of Applied Ecology, 50, 812-829.

[31] Robinson DA, Lebron I and Vereecken H. (2009). On the Definition of the Natural Capital of Soils: A Framework for Description, Evaluation, and Monitoring. Soil Sci. Soc. Am. J, 73, 1904-1911.

[32] Robinson DA, Fraser I, Dominati EJ, Davíðsdóttir B, Jónsson JOG, Jones L, Jones SB, Tuller M, Lebron I, Bristow KL, Souza DM, Banwart S and Clothier BE. (2014). On the value of soil resources in the context of natural capital and ecosystem service delivery. Soil Sci. Soc. Am. J. In press.

[33] Lopez Alonso M, Prieto Montana F, Miranda M, Castillo C, Hernandez J and Luiz Benedito. (2004). Interactions between toxic (As, $\mathrm{Cd}, \mathrm{Hg}$, and $\mathrm{Pb}$ ) and nutritional essential ( $\mathrm{Ca}, \mathrm{Co}, \mathrm{Cr}, \mathrm{Cu}, \mathrm{Fe}, \mathrm{Mn}, \mathrm{Mo}, \mathrm{Ni}, \mathrm{Se}$, $\mathrm{Zn}$ ) elements in the tissue of cattle from NW Spain. Biometals, 17(4), 389-97.

[34] Dominati E, Patterson M and Mackay A. (2010). A framework for classifying and quantifying the natural capital and ecosystem services of soils. Ecological Economics, 69, 1858-1868.

[35] Abdulla M and Chmielnicka J. (1990). New aspects on the distribution and metabolism of essential trace elements after dietary exposure to toxic metals. Boil Trace Elem Res, 23, 25-53.

[36] Boukhalfa C. (2007). Heavy metals in the water and sediments of Oued Es-Souk, Algeria, a river receiving acid effluents from an abandoned mine. Afr. J. Aquat. Sci, 2(3), 245-249.

\section{How to cite this article}

Adeoti OM, Ige ST, Abiola O, Adeoye KA and Olufemi SO. (2020). Assessing the potential risks of industrial soil of highly industrialized and less cities on plant growth. GSC Advanced Research and Reviews, 3(3), 11-19. 